$\left.\begin{array}{c}\text { praktyka } \\ \text { ansibljyiogt }\end{array}\right\}$
Praktyka Teoretyczna

Numer 3(29)/2018

ISSN 2081-8130

DOI: $10.14746 /$ prt.2018.3.0 www.praktykateoretyczna.pl

\title{
WCZESNY SOCJALIZM I PRZYSZŁOŚĆ
}

\author{
PIOTR KuligOWSKI
}

Naszym btedem nie jest, jak, zwykto sie sqdzic, to, że pragniemy zbyt wiele, lecz to, że pragniemy zbyt mato.

Charles Fourier ${ }^{1}$

Niewiele kategorii politycznych zrodzonych w ogniu gorącego sporu zrobiło równie zawrotną karierę, co „socjalizm utopijny”, który na wiele dekad zapuścił korzenie nie tylko w dyskursie politycznym, ale także w debatach akademickich. Wymowne, że szereg badaczy o wyraźnie antylewicowym nastawieniu zapożyczyło tę kategorię, użytą pierwotnie przez Marksa i Engelsa w Maniféście Partii Komunistycznej, w celu krytyki emancypacyjnych i postępowych ideałów. Marks i Engels tymczasem, co również warto podkreślić, określając tym właśnie terminem swych bądź co bądź ideowych poprzedników, odnosili się do znaczeniowych przesunięć, którym podlegała w początkach dziewiętnastego wieku kategoria utopijności. W czasach panowania Ludwika Filipa pojęcie „utopii” przestało określać nurt filozoficzny czy gatunek literacki, a zaczęło oznaczać trudny bądź niemożliwy do realizacji program polityczny. Powiązana z tą zmianą linia krytyki szczególnie uderzała w pierwszych socjalistów, którzy przyznawali sobie miano badaczy

\footnotetext{
${ }^{1}$ Cyt. za: Morilhat 1991, 26.
} 
społecznych i chętnie obnosili się ze swą naukową metodą poznania (Angenot 2003, 76-77). Śledząc współczesne debaty polityczne, trudno nie odnieść wrażenia, że utopijność rozumiana jako nierealność - wszelkich lewicowych projektów politycznych wciąż należy do ulubionych argumentów neoliberalnej prawicy.

Podstawowym celem niniejszego numeru jest próba ponownego spojrzenia na całokształt postaci, idei i zjawisk, które w literaturze były i - pomimo rosnącego krytycyzmu wciąż bywają opisywane jako emanacje socjalizmu utopijnego. By zrewitalizować i obronić zawartą w nich utopijność, na poniższych stronach określamy je mianem „wczesnego socjalizmu”. Cel tego gestu jest dwojaki. Po pierwsze, służy on przesunięciu ciężaru interpretacyjnego z rzeczywistej lub domniemanej utopijności poszczególnych nurtów socjalistycznych na moment ich powstania. Po drugie, ma on wskazać, że podejmowane przez przedstawicieli owych nurtów rozważania, zwłaszcza te prowadzone w duchu utopijnym, miały na celu przede wszystkim refleksje nad przyszłością. To właśnie nowa wizja przyszłości, w której wszystko - łącznie z daleko posuniętymi przeobrażeniami środowiska i klimatu miało być możliwe, wyróżnia wczesnych socjalistów na tle innych nurtów politycznych w pierwszych dekadach dziewiętnastego wieku.

Prezentowany numer wpisuje się tym samym w długa tradycję rekonceptualizacji nurtów wczesnosocjalistycznych, która, co paradoksalne, trwa od samego momentu ich powstania. Dość wspomnieć, że sam twórca pojęcia „socjalizm” (rozumianego początkowo jako brakujące przeciwieństwo „egoizmu”), Pierre Leroux, drwił z wizji zmian klimatycznych przewidywanych przez Charlesa Fouriera (Angenot 2003, 28). Dla jasności warto dopowiedzieć, że Fourier był przekonany o możliwości przekształcenia Sahary w kwitnący ogród, a także wierzył, że stopnienie lodowców spowoduje przemianę wody w oceanach w oranżadę. Słowem, podstawowa słabość kategorii utopijnego socjalizmu wiąże się z faktem, że sami socjaliści „utopijni”, traktując własną doktrynę jako opartą na naukowych przesłankach, odżegnywali się od utopizmu oraz używali go do krytyki politycznych oponentów (również lewicowych) (Paden 2002; Brémand 2014).

Oprócz tego wattpliwości budzi szeroki zakres znaczeniowy kategorii „socjalizmu utopijnego”. Wprawdzie Marks i Engels nie określili w ten sposób Cabeta, deklarującego się otwarcie jako komunista, jednak już wśród przedstawicieli francuskiej lewicy w wieku dziewiętnastym sprzeciw budziło traktowanie jako socjalistów Saint-Simona i Fouriera, a nawet samo zrównywanie ich bardzo odmiennych poglądów (Prochasson 1997, 61). Inni krytycy 
wskazywali z kolei, że stosowanie wspólnej kategorii do nazwania tak różnych zjawisk powoduje, że „socjalizm utopijny” należałoby w istocie datować od roku 1815, a zatem na długo przed powstaniem samego pojęcia „socjalizmu” (Bruhat 1972).

Próby zastapienia lub przedefiniowania kategorii socjalizmu utopijnego pojawiały się także w kręgach polskich lewicowców, między innymi w ramach debat akademickich. W 1923 roku Jerzy Kurnatowski zaproponował kategorię „socjalizmu zrzeszeniowego” (Kurnatowski 1923), zaś pół wieku później polscy socjaliści emigracyjni przejęli od historyków francuskich termin „socjalizm romantyczny” (Ciołkosz i Ciołkosz 1966). Irena Koberdowa zwracała uwage na konieczność włączenia tradycji socjalizmu utopijnego do badania dziejów ruchu robotniczego, które - jak wskazywała - były powszechnie datowane dopiero od roku 1878 (Koberdowa 1987; 1989). Wreszcie, w dyskusjach nad periodyzacją dziejów socjalizmu w Polsce pojawiła się również propozycja określenia „wczesny socjalizm” (Kalembka 1989), na której opiera się zamysł tego numeru.

Osłabieniu zakorzenionego w dyskursie politycznym i naukowym podziału na socjalizm utopijny i naukowy, czy też Marksowski i przedmarksowski, służyć może analiza funkcjonowania kolonii zakładanych przez przedstawicieli owych nurtów. Unikalnym materiałem, który może być użyteczny dla tego rodzaju dociekań, są wspomnienia Aleksandra Hołyńskiego z wizyty w ikaryjskiej kolonii w Nauvoo w 1855 roku. W opublikowanym w niniejszym numerze przekładzie owych wspomnień widać wyraźnie, że w trakcie poznawania warunków życia i zwyczajów Ikaryjczyków w Nauvoo autor rozdarty jest między skrajnymi emocjami, nieustannie balansuje między podziwem i drwina. Mimo zachowania krytycznego dystansu wobec projektu Cabeta i jego zwolenników Hołyński jest przekonany, że tego rodzaju wspólnota wdrożyła szereg pozytywnych rozwiązań, poprawiając warunki życia i skracając czas pracy zaangażowanych w nią osób. Drugim z tekstów, który umożliwi czytelnikom przyjrzenie się inicjowanemu przez wczesnych socjalistów ruchowi osadniczemu, jest artykuł Michela Cordillota na temat fourierowskiej kolonii La Reunion w Teksasie. Jak wskazuje autor, czas jej funkcjonowania był rzeczywiście krótki, ale wywarła ona długotrwały wpływ na życie zaangażowanych w ten projekt osób, co z kolei miało istotne znaczenie dla rozwoju ruchu socjalistycznego w Stanach Zjednoczonych. Dość wspomnieć, że byli koloniści, traktując epizod życia we wspólnocie jako jeden z jego istotnych etapów, a nie jako zasadniczą katastrofę, angażowali się w późniejszym okresie w działalność związków zawodowych oraz współtworzyli amerykańskie sekcje I Międzynarodówki. 
Tego typu analiza do pewnego stopnia unieważnia popularny w dyskusjach politycznych zarzut, który podnosi kwestię krótkotrwałości owych osadniczych przedsięwzięć. To właśnie ta kwestia otwiera przestrzeń dla ponownego przypatrzenia się „utopijności” nurtów wczesnosocjalistyczych. Zestawienie losów i doświadczeń kilkudziesięciu tego typu przedsięwzięć rozwijanych w wieku dziewiętnastym na terenie obu Ameryk wskazuje, że ich uczestniczki chętnie angażowały się w lokalne walki społeczne, zaś decyzja o wyjeździe - jak w przypadku Ikaryjczyków i Cabeta - wiązała się niejednokrotnie z utraconymi możliwościami legalnego działania i rozwijania ruchu w kraju pochodzenia (Johnson 1974, 238-241). Co więcej, trwałość określonych prób kontestacji porządku kapitalistycznego nie musi być traktowana jako warunek ich powodzenia. Działania punktowe, krótkotrwale, efemeryczne i powodujące miejscowe pęknięcia również moga zbliżać do wyjścia poza reżim oparty na wyzysku pracy najemnej (Antony 2016). Stwierdzenie, że po koloniach zakładanych przez zwolenników Owena, Cabeta czy Fouriera nic nie pozostało, byłoby uproszczeniem, gdyż to właśnie kolonistki i koloniści wynaleźli wiele narzędzi i udogodnień stosowanych również współcześnie. Wśród owych wynalazków warto wymienić między innymi płaską miotłę (wygodniejszą w użyciu od dawnych mioteł cylindrycznych, na przykład pęku brzozowych rózeg), obrotową tacę, klamerki, pierwszą pralkę automatyczną czy różnego typu obieraczki i przyrządy przyspieszające przygotowywanie posiłków (Jennings 2017). Jednak wyjazd do którejś z Ameryk i próba założenia kolonii to tylko jeden z etapów działania ruchów wczesnosocjalistycznych.

Utworzonemu przez Cabeta we Francji ruchowi ikaryjskiemu przygląda się od innej strony François Fourn, który bada działalność zaangażowanych weń osób w okresie poprzedzającym wyjazd pierwszej grupy osadników do Stanów Zjednoczonych. Inaczej niż autorzy, którzy twierdzą, że na poziomie zbiorowym o funkcjonowaniu ruchów wczesnosocjalistycznych decydowały emocje, a nie idee (por. Claeys 2014), Fourn wskazuje, w jaki sposób praktyki czytelnicze wpływały na integrację i funkcjonowanie tego największego pod względem liczby sympatyków ruchu politycznego we Francji za panowania Ludwika Filipa.

Tym, co niejednokrotnie przyciągało robotników i przedstawicieli wolnych zawodów do ruchów wczesnosocjalistycznych, była oferowana przez nie refleksja nad przyszłością, która niosła nadzieję i choć na moment wyrywała ich z kołowrotu codziennego życia. Jednym z przykładów takiej krzepiącej opowieści o tym, co możliwe, jest francuskojęzyczna broszura Prayszzłość kobiet autorstwa Jana Czyńskiego. Ta wydana w 1841 roku praca ukazuje się po raz 
pierwszy w języku polskim właśnie w prezentowanym numerze. Czyński wskazuje w niej, że w jego czasach położenie kobiet często wiązało się z prostytucją, wyzyskiem oraz brakiem swobody w wyborze zajęcia czy partnera. W przyszłości, czyli w zrealizowanym systemie „Harmonii”, kobieta będzie jednak mogła w sposób swobodny realizować swoje pasje i spełniać swe pragnienia.

Innym specyficznym sposobem opowieści o przyszłości jest religia - kolejna zapowiedź nadejścia wiecznego szczęścia i odkupienia. Czerpane wprost z języka religijnego metafory nie bez powodu były popularne wśród części wczesnych socjalistów. Kwestię tę na przykładzie idei politycznych Wilhelma Weitlinga analizuje Anton Jansson. Opierając się na trzech najważniejszych tekstach niemieckiego rewolucjonisty, autor pokazuje, w jaki sposób przy użyciu języka religijnego rozwijane są tam idee komunistyczne. Jak podkreśla Jansson, sięganie po tego rodzaju środki wyrazu lokuje Weitlinga w ramach szerszej tradycji wczesnosocjalistycznej refleksji, która stosunkowo często sięgała po takie metafory jak Chrystus na barykadzie czy Królestwo Boże na ziemi po to, aby uczynić swój przekaz bardziej przystępnym dla przedstawicieli klas ludowych. Widać zatem, że orientacja ku przyszłości oznaczała nie tylko określenie nowego horyzontu oczekiwań, ale również poszukiwanie nowych narzędzi, które mogłyby posłużyć do całkowitej transformacji świata.

O tym, w jaki sposób ta transformacja była opowiadana i jak miała być realizowana przez polskich socjalistów w dziewiętnastym wieku, traktuje w swym artykule Jan Kozubowski. Autor ten, czerpiąc z filozofii politycznej Alaina Badiou i Slavoja Žižka, posługuje się kategorią „idei komunistycznej”. Przyglądając się za jej pomocą ideom Zenona Świętosławskiego i Kazimierza Kelles-Krauza (oraz ich środowisk politycznych), Kozubowski dokonuje gestu rekoncyliacji „wczesnego” i „dojrzałego” socjalizmu. Wskazuje, że oba te nurty miały ze sobą wiele wspólnego w zakresie kontestacji kapitalizmu i proponowaniu określonej wizji nowego świata.

W ten sposób numer, który opowiada się za odrzuceniem kategorii „socjalizmu utopijnego" jako nieadekwatną i nadmiernie uwarunkowaną politycznie, proponuje zarazem obronę utopijności. Utopijność ta, którą można dostrzec również w aktywnościach ruchów wczesnosocjalistycznych, opiera się przede wszystkim na odważnym poszerzaniu politycznej wyobraźni i tego, co uznajemy za możliwe do osiagnięcia. W sposób nieco przewrotny intencję tę wspiera tekst Simona Springera pod wymownym tytułem Jebać neoliberalizm. Kanadyjski geograf czyni w nim polemiczny wobec status quo gest, który - do pewnego stopnia - powiela 
decyzje ikaryjskich awangard czy fourierystów wyjeżdżających z rodzinnych domów z silnym przekonaniem o konieczności radykalnego zakwestionowania otaczającego ich świata. „Jebanie neoliberalizmu" to wszak więcej niż czysto akademicka krytyka - to wykrzyczenie, za pomoca swoiście użytej formy eseju akademickiego, sprzeciwu wobec systemu, po którym nie można się już spodziewać niczego dobrego.

O ile zatem tekst Springera, ,jebiąc”, radykalnie neguje neoliberalny porządek, o tyle refleksja nad nurtami wczesnosocjalistycznymi otworzyć może pojemny rezerwuar zapomnianych sporów, marzeń i czynów, w których współczesna czytelniczka odnajdzie tak potrzebne dziś utopijne nadzieje. Tylko dzięki nim polityczne pragnienia warte tego miana znów będą możliwe.

\section{Wykaz literatury}

Angenot, Marc. 2003. Contre le socialisme: essai d'histoire discursive: 1830-1917. Montreal: Université McGill.

Antony, Michel. 2016. "Les communautés utopiques sont-elles toujours condamnées à disparaitre?”. Cahiers d'histoire. Revue d'histoire critique [En ligne] 133, http://chrhc.revues.org/5480.

Brémand, Nathalie. 2014. "Introduction: « Socialistes utopiques », les mal-nommés”. Cahiers d'histoire. Revue d'histoire critique [En ligne] 124. http://chrhc.revues.org/3659.

Bruhat, Jean. 1972. "Le Socialisme français de 1815 à 1848”. W Jacques Droz (ed.). Histoire générale du socialisme. Vol. 1: Des origines à 1875. Vendôme: Presses Universitaires de France: 330-406.

Ciołkosz, Adam i Lidia Ciołkosz. 1966. Zarys dziejów socjalizmu polskiego. T. I. Londyn: Gryf Publications LTD.

Claeys, Gregory. 2014. "Early Socialism as Intellectual History". History of European Ideas 40.7: 893-904.

Jennings, Chris. 2017. Paradise Now: The Story of American Utopianism. New York: Random House.

Johnson, Christopher H. 1974. Utopian Communism in France: Cabet and the Icarians, 1839-1851. Ithaca-London: Cornell University Press.

Kalembka, Sławomir. 1989. „Propozycja periodyzacji dziejów ideowych wczesnego socjalizmu polskiego". W Józef Kulas (red.). Gromady Ludu Polskiego: Materiały z sesji naukowej. Warszawa: Akademia Nauk Społecznych PZPR: 49-55.

Koberdowa, Irena. 1987. „Kształtowanie się wizji socjalizmu w polskiej myśli politycznej w latach 1830-1886. W Jan Tomicki (red.). Wizje socjalizmu w Polsce do roku 1948. Warszawa: Książka i Wiedza: 9-56.

Koberdowa, Irena. 1989. „Polska rewolucyjna myśl społeczna na tle myśli europejskiej w połowie XIX wieku”. W Józef Kulas (red.). Gromady Ludu Polskiego: Materiały z sesji naukowej. Warszawa: Akademia Nauk Społecznych PZPR: 7-15.

Kurnatowski Jerzy. 1923. Nowa ekonomia. http://lewicowo.pl/nowa-ekonomia/. 
Morilhat, Claude. 1991. Charles Fourier, imaginaire et critique sociale. Paris: MéridiensKlincksieck.

Paden, Roger. 2002. "Marx's Critique of the Utopian Socialists”. Utopian Studies 13.2: 67-91. Prochasson Christophe. 1997. Les intellectuels et le socialisme: XIXe-XXe siècle. Paris: Plon.

CytowaniE: Kuligowski, Piotr. 2018. „Wczesny socjalizm i przyszłość” Praktyka Teoretycz̨na 3(29): 8-14.

DOI: $10.14746 /$ prt.2018.3.0

AUTHOR: Piotr Kuligowski

TITLE: Early Socialism and the Future

ABSTRACT: : A short introduction to a special issue of Theoretical Practice, entitled "Early Socialism and the Future."

KEYWORDS: early socialism, the future, the $19^{\text {th }}$ century, utopian socialism 